\title{
Pengaruh Geometrik dan Lingkungan Jalan Pada Kecelakaan Lalulintas di Jalan perkotaan
}

\author{
Eri Rihandiar \\ Program Studi Teknik Sipil, Fakultas Teknik UNSUR \\ eri.rihandiar@yahoo.com
}

\begin{abstract}
Abstrak
Jalan perkotaan merupakan prasarana yang sangat penting dalam menunjang aktivitas sosial dan ekonomi penduduk perkotaan. Karena itu perlu diciptakan suatu sistem transportasi jalan perkotaan yang lancar, aman dan selamat. Pengenalan terhadap karakteristik geometrik dan lingkungan jalan yang diperkirakan berpengaruh terhadap kecelakaan lalulintas diharapkan dapat memberi kontribusi terhadap pengembangan desain geometrik dan lingkungan jalan yang berwawasan keselamatan.

Pada studi ini dilakukan pengembangan model prediksi kecelakaan lalulintas yang dapat memperkirakan potensi keselamatan jalan. Beberapa variabel geometrik dan lingkungan jalan yang diperkirakan mendasari terjadinya kecelakaan lalulintas dikaji, dan kemudian dengan analisis regresi linier dikembangkan model yang menjelaskan hubungan terjadinya kecelakaan lalulintas sebagai fungsi dari variabel-variabel tersebut. Variabel geometrik dan lingkungan jalan yang dikaji meliputi panjang segmen, lebar jalan, jumlah simpang tanpa lampu lalulintas, volume lalulintas, median dan hambatan samping.

Hasil penelitian menunjukan bahwa diantara variabel-variabel yang diteliti, variabel yang memiliki pengaruh yang cukup signifikan terhadap terjadinya kecelakaan lalulintas adalah volume lalulintas, lebar jalan dan jumlah simpang tanpa lampu lalulintas pada suatu segmen jalan. Semakin banyak jumlah simpang tanpa lampu lalulintas pada suatu segmen jalan, jumlah kecelakaan akan semakin meningkat. Pada jalan yang lebih lebar dan volume lalulintas lebih tinggi, kecelakaan lalulintas cenderung berkurang.
\end{abstract}

Kata kunci: kecelakaan lalulintas, geometrik dan lingkungan jalan, model prediksi kecelakaan.

\section{Pendahuluan}

Tingkat keselamatan lalulintas di jalan raya di Indonesia relatif masih sangat rendah. Hal ini ditunjukan dengan tingginya jumlah kecelakaan lalulintas di Indonesia dibandingkan dengan negara-negara maju. Data dari Kepolisian Negara Republik Indonesia mencatat sebagian besar kecelakaan lalulintas terjadi di wilayah perkotaan. Hal ini bisa dimaklumi karena sebagian besar mobilisasi kendaraan dan titik konflik lalulintas terkonsentrasi di wilayah perkotaan.

Persoalan keselamatan lalulintas di jalan raya di Indonesia, khususnya di perkotaan, dalam banyak hal berbeda dengan persoalan yang terjadi di negara-negara maju. Sebagai contoh, tingkat urbanisasi yang tinggi serta peningkatan jumlah kendaraan yang tidak diimbangi oleh pertumbuhan prasarana jalan menyebabkan terjadinya kemacetan lalulintas dan meningkatnya jumlah kecelakaan lalulintas di jaringan jalan yang ada, yang pada awalnya tidak direncanakan untuk melayani jumlah dan jenis lalulintas yang sekarang menggunakannya. Selain itu, pertumbuhan daerah urban yang tidak direncanakan dengan baik menyebabkan penggunaan lahan dan jaringan jalan yang tidak sesuai, dengan banyaknya konflik antara pejalan kaki dengan arus lalulintas.

Jalan perkotaan merupakan prasarana yang sangat penting dalam menunjang aktivitas sosial dan ekonomi penduduk perkotaan. Pilihan manajemen yang ditujukan untuk perbaikan mobilitas lalulintas di jalan perkotaan hendaknya mempertimbangkan keselamatan jalan. Karakteristik jalan merupakan salah satu faktor penyebab kecelakaan selain faktor manusia dan faktor kendaraan. Dilain pihak, pembangunan fisik jalan dan lingkungan jalan di Indonesia dewasa ini masih jarang memasukan pertimbangan keselamatan secara khusus.

Kecelakaan lalulintas di jalan sesungguhnya dapat dieleminir dengan mengenali pengaruh karaktristik jalan terhadap kejadian kecelakaan. 
Untuk itu diperlukan suatu metode untuk mengevaluasi kecelakaan lalulintas yang seyogyanya terintegrasi dengan desain jalan. "Model Prediksi Kecelakaan" merupakan metode/alat berharga yang dapat digunakan untuk mengevaluasi keselamatan jalan. Model tersebut merupakan model matematik yang mencoba mengkaitkan kejadian kecelakaan pada berbagai karakteristik geometrik dan lingkungan jalan.

\section{Tujuan Studi}

Tujuan studi ini adalah untuk mengembangkan model prediksi kecelakaan yang dapat memperkirakan potensi kecelakaan lalulintas di jalan perkotaan berdasarkan kondisi geometrik dan lingkungan jalan.

Pada studi ini akan diteliti hubungan antara jumlah kecelakaan lalulintas yang terjadi pada suatu ruas jalan dengan variabel-variabel geometrik jalan, volume lalulintas dan lingkungan jalan dan menjelaskannya dalam pengertian statistika. Variabel-variabel seperti panjang jalan, lebar jalan, median, jumlah simpang tanpa lampu lalulintas, volume lalulintas dan hambatan samping, akan dikaji pengaruhnya terhadap peluang terjadinya kecelakaan lalulintas.

\section{II. Manfaat Studi}

Hasil studi ini diharapkan dapat memberi kontribusi terhadap peningkatan kualitas keselamatan jalan khususnya pengurangan angka kecelakaan lalulintas. Pengenalan terhadap karakteristik geometrik dan lingkungan jalan di perkotaan yang paling berpengaruh terhadap terjadinya kecelakaan, diharapkan dapat memberi kontribusi terhadap pengembangan desain jalan perkotaan yang berwawasan keselamatan. Lebih jauh lagi, secara praktis "Model Prediksi Kecelakaan" dapat digunakan untuk mengidentifikasi dan menyusun rangking lokasi rawan kecelakaan.

\section{Kecelakaan Lalulintas}

Kecelakaan lalulintas adalah suatu peristiwa di jalan yang tidak disangka-sangka dan tidak disengaja, yang melibatkan korban manusia atau kerugian harta benda.

Beberapa penyebab kecelakaan lalulintas yang akan diuraikan berhubungan dengan faktor manusia, faktor kendaraan, faktor jalan dan lingkungan. Walaupun demikian faktor-faktor tersebut tidak dapat berdiri sendiri, karena setiap faktor akan terkait satu dengan yang lain.

\subsection{Faktor Manusia}

Manusia, dalam arti luas merupakan faktor dominan yang mempengaruhi timbulnya kecelakaan lalulintas. Sebagai pengemudi kendaraan, manusia berhubungan langsung dengan keselamatan. Pengemudi dapat mengatur pergerakan kendaraan, dengan mempercepat, memperlambat atau menghentikannya. Sikap pengemudi yang sangat berpengaruh dalam mengendalikan kendaran adalah pribadinya, latihan dan sikap (Oglesby dan Hick, 1982).

Mengemudi kendaraan merupakan pekerjaan yang komplek. Selama mengemudi, pengemudi langsung berinteraksi dengan kendaraan serta menerima dan menerjemahkan rangsangan disekelilingnya terus menerus. Kondisi jalan dengan perkerasan stabil berdampak pengemudi merasa nyaman dalam mengemudi. Kondisi ini mendorong pengemudi menjalankan kendaraan dengan kecepatan tinggi dan kewaspadaan pengemudi menurun yang akan berakibat mudah timbulnya kecelakaan. (Ogden dan Taylor, 1999).

\subsection{Faktor Kendaraan}

Unsur terpenting dari terjadinya pergerakan yang selalu mengalami perkembangan dan kemajuan pesat adalah moda angkutan. Kendaraan sebagai sarana transportasi mempunyai peranan besar terhadap tingkat keselamatan lalulintas di jalan. Dengan kemajuan teknologi yang sangat modern telah merubah peradaban manusia, pergerakan dapat dilakukan dengan cepat. Hanya kendaraan yang laik saja yang seharusnya boleh beroperasi di jalan, pada kenyataannya, banyak kendaraan yang kondisinya sangat memprihatinkan masih beroperasi di jalan raya.

\subsection{Faktor Jalan dan Lingkungan}

Karakteristik jalan berpengaruh sebagai penyebab kecelakaan lalulintas. Perbaikan terhadap kondisi jalan akan mempengaruhi pula terhadap karakteristik kecelakaan yang terjadi. Kondisi jalan yang dapat menyebabkan terjadinya kecelakaan adalah kerusakan pada permukaan jalan dan geometrik jalan yang kurang sempurna. Kondisi tata guna lahan, sistem perparkiran, kondisi cuaca serta 
pengaturan lalulintas adalah beberapa komponen yang diperkirakan berpengaruh terhadap kecelakaan lalulintas.

\subsection{Analisis Kecelakaan Lalulintas}

Kecelakaan lalulintas dianalisis dengan menggunakan data yang sudah ada. Identifikasi lokasi rawan kecelakaan lalulintas merupakan penentuan lokasi kecelakaan terburuk atau lokasi rawan kecelakaan yang memiliki prioritas tertinggi untuk mendapatkan penanganan. Identifikasi tersebut antara lain dapat dilakukan dengan pendekatan jumlah kecelakaan atau tingkat kecelakaan. Penggunaan tingkat kecelakaan menggunakan rumus : (Departemen Permukiman dan Prasarana Wilayah, 2004)

$$
\mathrm{Tk}=\frac{\text { Fk x } 100^{8}}{- \text { LHRT } \times \mathrm{n} \times \mathrm{L} \times 365}
$$

dengan :

$\begin{aligned} \mathrm{Tk}= & \begin{array}{l}\text { Tingkat kecelakaan }(100 \text { juta } \\ \text { perjalanan kendaraan-kilometer })\end{array} \\ \mathrm{Fk}= & \begin{array}{l}\text { Frekuensi kecelakaan di ruas jalan } \\ \text { untuk } \mathrm{n} \text { tahun data }\end{array} \\ \mathrm{LHRT}= & \begin{array}{l}\text { Lalulintas Harian Rata-Rata Tahunan } \\ \text { (kend/hari) }\end{array} \\ \mathrm{N}= & \text { Jumlah tahun data } \\ \mathrm{L} & =\text { Panjang ruas jalan }(\mathrm{km})\end{aligned}$

\subsection{Regresi Linier Berganda}

Salah satu cara yang dapat digunakan untuk menganalisis penyebab kecelakaan lalulintas adalah dengan menggunakan persamaan regresi. Ini merupakan salah satu cara statistik yang digunakan untuk menghasilkan hubungan yang dinyatakan dalam angka, antara satu variabel dengan variabel lain. Cara ini digunakan untuk melihat bagaimana dua variabel atau lebih saling terkait

Teknik regresi linier berganda dapat digunakan untuk menganalisis hubungan antara satu variabel tidak bebas dan satu atau lebih variabel bebas. Untuk memudahkan perhitungan regresi berganda berikut uji signifikansi dan uji asumsi yang cukup rumit, diperlukan alat bantu program komputer. Model umum dari persamaan yang dihasilkan adalah :

$$
\mathrm{Y}=\mathrm{b}_{0}+\mathrm{b}_{1}+\mathrm{b}_{2} \mathrm{X}_{2}+\ldots .+\mathrm{b}_{\mathrm{k}} \mathrm{x}_{\mathrm{k}}
$$

Dengan :

$\mathrm{Y} \quad=\quad$ variabel tidak bebas
$\mathrm{X}_{1}, \mathrm{X}_{2}, \ldots \mathrm{X}_{\mathrm{k}}=$ variabel bebas $\mathrm{b}_{0}, \mathrm{~b}_{1}, \mathrm{~b}_{2} \ldots \mathrm{b}_{\mathrm{k}}=$ koefisien regres

V. Studi Kasus

Pada studi ini ruas jalan yang ditinjau adalalah beberapa ruas jalan dengan klasifikasi jalan arteri primer, arteri sekunder, kolektor primer dan kolektor sekunder di kota Bandung. Pendataan kecelakaan lalulintas di ruas-ruas jalan tersebut tersedia lebih lengkap dengan adanya pos-pos polisi, rutinitas patroli polisi, dan rumah sakit sebagai instansi/lembaga yang berkepentingan dalam pendataan kecelakaan lalulintas. Dalam menyusun model prediksi kecelakaan ini tidak dilakukan pemisahan antara klasifikasi jalan tersebut diatas dengan alasan geometrik jalan, volume lalulintas dan lingkungan jalan di kota Bandung tidak mempunyai batasan jelas yang dapat membedakan klasifikasi jalan tersebut. Dengan alasan yang sama, Model Prediksi Kecelakaan hasil penelitian ini bisa diterapkan untuk seluruh jalan utama/mayor di kota Bandung

\subsection{Skema Studi}

Skema studi merupakan gambaran urutan kegiatan studi dari awal bagaimana data diperoleh, bagaimana mengolahnya, dan metode yang dipakai sehingga dapat diperoleh suatu model prediksi kecelakaan. Dari model yang dihasilkan kemudian dapat dijelaskan hubungan antara jumlah kecelakaan lalulintas yang terjadi pada suatu segmen jalan dengan karakteristik volume lalulintas, geometrik dan lingkungan jalan.

\subsection{Pengumpulan Data}

Sesuai dengan tujuan dari penelitian ini, yaitu untuk mengembangkan model yang menghubungkan kecelakaan lalulintas dengan kondisi geometrik dan lingkungan jalan, maka dilakukan pengumpulan dan pengelompokan data. Data yang dikumpulkan adalah data kecelakaan lalulintas serta data geometrik dan lingkungan jalan pada ruas-ruas jalan arteri dan kolektor kota Bandung, selama periode tahun 2010

\subsubsection{Data Kecelakaan Lalulintas}

Parameter kecelakaan lalulintas yang dikumpulkan meliputi lokasi dan waktu kecelakaan. Yang dimaksud dengan kecelakaan disini adalah seluruh kecelakaan lalulintas tanpa membedakan tipe tubrukan, jenis luka korban atau keterlibatan jenis kendaraan. 
Dalam studi ini, untuk mendapatkan data kecelakaan selengkap mungkin dilakukan pengumpulan data dari lembaga Kepolisian dan Rumah Sakit. Teknik pengumpulan data yang dilakukan adalah dengan mendata kecelakan lalulintas di Kepolisian, kemudian melakukan pengecekan silang dengan data kecelakaan lalulintas di Rumah Sakit. Pengecekan silang data kecelakaan lalulintas dapat diidentifikasi dari waktu (bulan, hari, dan jam), identitas pelaku, keterlibatan kendaraan dan lokasi kendaraan.

\subsubsection{Data Geometrik dan Lingkungan Jalan}

Data yang dikumpulkan meliputi data lebar dan panjang jalan, jumlah simpang, jumlah jalur atau keberadaan median, keberadaan lampu lalulintas, hambatan samping, dan volume lalulintas harian rata-rata tahunan (LHRT) pada ruas-ruas jalan arteri dan kolektor kota Bandung.

\subsection{Pengelompokan Data}

Kegiatan pengelompokan data meliputi dua tahapan, yaitu tahap segmentasi jalan dan tahap identifikasi lokasi kecelakaan lalulintas. Pengelompokan data dilakukan untuk memperoleh hubungan antar segmen jalan dengan jumlah kecelakaan yang terjadi di segmen tersebut.

\subsubsection{Segmentasi Jalan}

Langkah awal dalam kegiatan pengelompokan data adalah pembuatan segmentasi terhadap ruasruas jalan yang ditinjau. Pada penelitian ini segmen jalan diidentifikasikan sebagai panjang jalan yang terletak diantara simpang yang saling berdekatan dan mempunyai karakteristik yang hampir sama sepanjang jalan. Karakteristik yang dimaksud adalah lebar jalan, adanya median atau kanalisasi, dan volume lalulintas. Titik dimana karakteristik jalan berubah secara berarti menjadi batas segmen walaupun tidak ada simpang bersinyal didekatnya. Perubahan kecil dalam geometrik diabaikan (misalnya perbedaan lebar jalur lalulintas kuran dari $0,5 \mathrm{~m}$ ), terutama jika perubahan tersebut hanya sebagian.

\subsubsection{Identifikasi Lokasi Kecelakaan Terhadap Segmen Jalan}

Langkah selanjutnya dari kegiatan pengelompokan data adalah mengidentifikasi lokasi kecelakaan terhadap segmen jalan yang telah ditentukan. Untuk kasus-kasus kecelakaan yang dilanjutkan ke pengadilan atau mengajukan klaim asuransi, identifikasi cukup mudah dilakukan karena data lokasi kecelakaan cukup jelas, dilengkapi denah lokasi. Sementara untuk kasus kecelakaan lainnya, proses identifikasi dilakukan dengan cara identifikasi lapangan.

Hasil akhir dari pengelompokan data adalah hubungan antara segmen jalan dengan jumlah kecelakaan yang terjadi di segmen tersebut.

\section{Data dan Analisis}

Sesuai tujuan studi, data yang ada dianalisis untuk memperoleh suatu persamaan yang menyatakan hubungan antara jumlah kecelakaan lalulintas pada suatu ruas/segmen jalan per tahun dengan variabel-variabel geometrik dan lingkungan jalan yang diduga berpengaruh terhadap terjadinya kecelakaan lalulintas. Untuk mendapatkan persamaan tersebut digunakan data jumlah kecelakaan lalulintas yang terjadi pada suatu ruas/segmen jalan dalam kurun waktu satu tahun sebagai variabel tidak bebas, dan data untuk variabel bebas adalah data panjang ruas/segmen jalan, lebar perkerasan jalan, jumlah simpang tanpa lampu lalulintas, volume lalulintas, media dan hambatan samping. Ringkasan data statistik kecelakaan lalulintas, geometrik dan lingkungan jalan disajikan pada Tabel 1. Data hubungan jumlah kecelakaan dengan geometrik dan lingkungan jalan untuk masing-masing segmen jalan disajikan pada Tabel 2 dan Tabel 3.

Tabel 1. Ringkasan Data

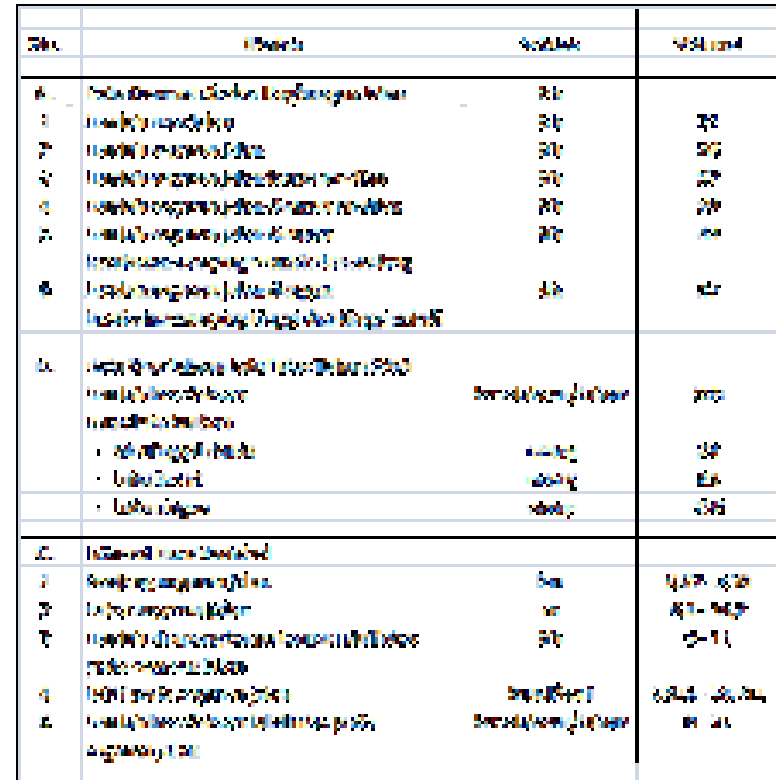


Tabel 2. Data Hubungan Jumlah Kecelakaan Dengan Geometrik dan Lingkungan Jalan Untuk Pembentukan Model Regresi.

\begin{tabular}{|c|c|c|c|c|c|c|c|}
\hline 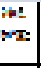 & 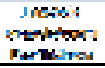 & 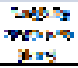 & 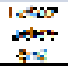 & 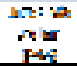 & 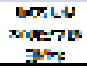 & 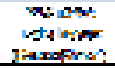 & $\begin{array}{l}\text { IBraniss } \\
\text { stwones }\end{array}$ \\
\hline 5 & $s$ & $\mathrm{ks}$ & 9 & 5 & $=$ & $r=x$ & sana: \\
\hline$=$ & + & oes. & $=$ & 1 & 2 & $\because \mathrm{ze}$ & stoatst \\
\hline 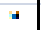 & 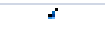 & $\infty$ & $: 2$ & $\Rightarrow$ & $=$ & rinet & indet \\
\hline$e$ & 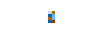 & $a x$ & $\therefore$ & $=$ & $=$ & misa & $\log$ \\
\hline a & - & ع إ. & 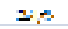 & .1 & $\Rightarrow$ & anus & inor \\
\hline ; & 8 & $x y$ & is & $\%$ & $\Rightarrow$ & 2646 & $x+x_{0}$ \\
\hline$\therefore$ & 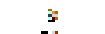 & bis & $\because$ & 1 & $r$ & xalc & max: \\
\hline$\therefore$ & 0 & 番 & $\leq$ & $\therefore$ & 2 & $x \times 00$ & $\min : x$ \\
\hline 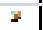 & $\theta$ & net & . : & 2 & 4 & W. & morer \\
\hline 部 & 8 & $\omega$ & $\Rightarrow 2$ & - & s & $x: F$ & $-\infty$ \\
\hline 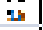 & $=$ & ser & $\infty$ & 1 & $=$ & 제. & Whor \\
\hline I. & $=$ & $a E$ & $\Rightarrow$ & $x$ & e & $\pi$ In & $=0$ \\
\hline 2x & th & 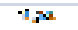 & $\Delta r$ & $=$ & a & "C.Ma & $x \rightarrow \infty$ \\
\hline 20 & 26 & 1,58 & $x$ & $i$ & $\ddot{y}$ & $3 \times r$ & nom \\
\hline$\perp$ & $=$ & ant & $z$ &. & - & 32.2 & $m \rightarrow=$ \\
\hline$\approx$ & $z$ & $\Delta=$ & $\rightarrow 2$ & $x$ & $=$ & $k=4$ & Yankes a \\
\hline if & a & se & $\Rightarrow$ & $j$ & $=$ & $x+4$ & $\sin x$ \\
\hline$\approx$ & : & $\infty$ & $\leqslant$ & $=$ & 5 & neit & Drains \\
\hline אי & $s$ & aw & $x>$ & ${ }_{1}$ & $=$ & Aiבa? & $\rightarrow$ \\
\hline$\pi$ & $=$ & wos & $>K$. & $z$ & $\mathrm{~g}$ & oriment & mexti \\
\hline. & $\pi$ & .30 & $a$ & s & a & pres & imess: \\
\hline$s$ & 4 & 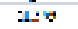 & a & ה & .7 & \$:จ1 & mose \\
\hline$\star 4$ & ๘ & $a \times 2$ & 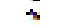 & 7 & 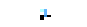 & pexpop & $m$ \\
\hline$=$ & $:$ & asi & $=$ & 8 & כ & $30 \times 2 x$ & mrast \\
\hline - & I & .320 & 2 & 1 & i & wase & $x-2 x-x_{2}$ \\
\hline 8 & $\approx$ & רוז & 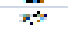 & $\overrightarrow{-1}$ & 5 & $x-\operatorname{sen}$. & $\sin \theta$ \\
\hline 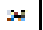 & 4 & A & is & 1 & $\lambda$ & Fas & $-\infty \times m$ \\
\hline$\because$ & $\therefore$ &. & $20 x$ & .1 & $=$ & $\pi=\Delta s$ & mils \\
\hline$=1$ & 7 & 0,8 & $\ldots$ & 2 & $=$ & $\rightarrow x \times$ & \#xtes \\
\hline 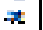 & $\rightarrow$ & 0.4 & 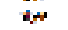 & j & $>$ & $\Rightarrow+8$ & w \\
\hline is & $\because$ & $9 x$ & $=0$ & $\because$ & $B$ & $x-0$ & tratis $x$ \\
\hline 20 & $=$ & sion & $=8$ & $\boldsymbol{Y}$ & $\approx$ & t.ss & W.00:s \\
\hline se & $=$ & Gri & $\infty$ & $\therefore$ & $=$ & $-2 x=$ & $=0 \times x \leqslant$. \\
\hline$\approx$ & $z$ & $\mathrm{var}$ & $\infty$ & $A$ & $\Rightarrow$ & theos & m $\rightarrow 6$ : \\
\hline$\infty$ & ב & Its & 17 & .2 & 4 & 2xis & $x+2 x$ \\
\hline$\approx 0$ & $\rightarrow$ & $-1, n$ & $\because$ & $\nu$ & $a$ & mosen & $m v:=$ \\
\hline $\boldsymbol{x}$ & $\infty$ & 43 & $\because$ & 2 & a. & size: & wass \\
\hline $1 z$ & : & a:s. & 2 & .1 & 5 & rasn & 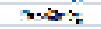 \\
\hline 2 & $\infty$ & 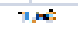 & 3 & $\pi$ & $\Rightarrow$ & $\operatorname{sen}$ & $y=x^{2} x$ \\
\hline to & $\neq$ & eso & 4 & 2 & 2 & MLPo & $\ln x y$ \\
\hline$=$ & $\because$ & Q & $s \underline{x}$ & . & $\therefore$ & stoms & whrs \\
\hline 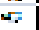 & 5 & $\sec$ & JE & ${ }_{1}$ & 2 & 20sto & $\rightarrow \infty$ \\
\hline$\approx$ & $m$ & 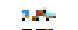 & $=x$ & 7 & $x$ & ; & $m$ \\
\hline$\approx$ & 3 & $\theta \infty$ & שs & $=$ & $=$ & Si:. & - \\
\hline$\omega$ & 8 & 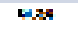 & 22 & 2 & $=$ & zoas & $\operatorname{mos}$ \\
\hline
\end{tabular}

Tabel 3. Data Hubungan jumlah kecelakaan Dengan Geometrik dan Lingkungan Jalan untuk Validasi Silang.

\begin{tabular}{|c|c|c|c|c|c|c|c|}
\hline$x_{\infty}^{\infty}$ & 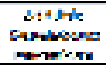 & $\begin{array}{l}\text { mative } \\
\text { ingem } \\
\text { inden }\end{array}$ & 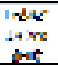 & 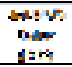 & $\begin{array}{l}2: \text { wht } \\
\text { tiwes } \\
\text { tws }\end{array}$ & Whotions & 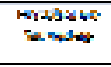 \\
\hline$\alpha$ & 3 & $=\pi$ & $5=$ & $x$ & $E$ & 250 & $9 x_{j}=6 \mathrm{mg}$ \\
\hline & $<$ & $2 \%$ & का & 1 & $v$ & antses & wor:? \\
\hline$z$ & $\mathrm{z}$ & $3 \pi$ & 147 & 2 & 4 & Test & Sats \\
\hline .6 & 2 & . 28 & 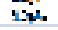 & ; & $s$ & $30 \pi$ & Solous \\
\hline$\Rightarrow$ & $F$ & $\Leftrightarrow$ & 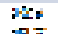 & $?$ & 3 & 270 & in. \\
\hline$a$ & $=$ & ise & $=2 \pi$ & 1 & 1 & 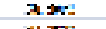 & $\ln x^{\prime}$ \\
\hline 5 & ल & $x=3$ & $\operatorname{sen}$ & 3 & 3 & $\therefore \approx$ & וm: \\
\hline :y & 4 & $5 \%$ & $x_{x}=$ & 2 & $\approx$ & $2 \ln 2 x$ & Nont \\
\hline$=$ & $s$ & ors & 56. & ? & 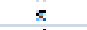 & 570 & nos \\
\hline$\pi$ & त & $\rightarrow \infty$ & $\because$ & $x$ & 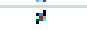 & $5 \sin x$ & $\min$ \\
\hline 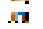 & $\ddot{x}$ & $a$ & 2 & $i$ & 3 & sows & $m_{n e s}$ \\
\hline 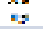 & 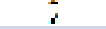 & 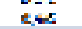 & $x$ & $x$ & 5 & ande & restent \\
\hline$\approx x$ & m & $6 x^{\circ}$ & $\pi$ & 5 & $x$ & sneses & $x=0$, \\
\hline$\approx$ & $y$ & 5 & $x$ & $=$ & 4 & $=0 x$ & sears \\
\hline 4 & $\pi$ & $1,0 x$ & 7 & $\bar{z}$ & 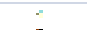 & $4 \times \infty$ & andots \\
\hline 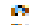 & 5 & $\operatorname{sen}$ & $\pi$ & $\tau$ & n & 7 The & neate: \\
\hline 2 & 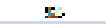 & 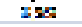 & $x$ & $i$ & $\&$ & sitea & maries \\
\hline vat & $\lambda$ & $2 x$ & $x$ & $\pi$ & 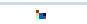 & 48 & Fentrot \\
\hline 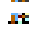 & i & isa & $\partial F$ & 2 & $z$ & $\infty$ & $30=3$ \\
\hline & 26 & $>\infty$ & $x, 8$ & $=$ & $=$ & $=x<x$ & $\operatorname{las}$ \\
\hline$\because$ & $\eta$ & $\mathrm{Nor}$ & $\geqslant$ & $x$ & 2 & $x+\infty$ & nos: \\
\hline$\Rightarrow$ & 8 & $=0$ & 3 & s & $\pi$ & צר & $n+2$ \\
\hline 36 & i & thr & 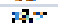 & 7 & $\nabla$ & $\Rightarrow x=14$ & rea: \\
\hline הa & $=$ & ines & 20,1 & i & 8 & $\cos x$ & $\pi$. \\
\hline .4 & $=$ & $14=5$ & $23 \%$. & $i$ & $\approx$ & siser & $\operatorname{sen} x$ \\
\hline$-x$ & $\approx$ & 20 & $\infty \times$ & 7 & $x$ & $x .76$ & nans \\
\hline$\therefore$ & 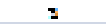 & $x=0$ & 3.206 & $i$ & $=$ & 205 & $\ln x:$ \\
\hline :34 & $=$ & $x=0$ & $\mathrm{AR}$ & $i$ & A & $\tan x$ & $10=$ \\
\hline$\therefore$ & 4 & $2 x$ & 10 & 3 & 3 & ation & Wh: \\
\hline 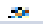 & $n$ & $5, \pi s$ & $\therefore$ & 1 & , & 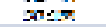 & seres. \\
\hline$\geqslant$ & 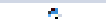 & $d \pi$ & $\therefore$ & 7 & $\bar{n}$ & 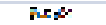 & 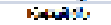 \\
\hline$\Leftrightarrow$ & $\dot{x}$ & הכבנ & $x z$ & I & $=$ & $a=2$ & $n \times$ \\
\hline$\because 1$ & $\approx$ & 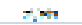 & $x_{x}$ & 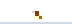 & $v$ & $D=0$ & notion \\
\hline$\because 4$ & $\bar{z}$ & נהק & 72 & $>$ & s & $x \rightarrow \infty x$ & $\Leftrightarrow<0_{1}$ \\
\hline $\boldsymbol{\alpha}$ & 2 & $\Leftrightarrow$ & $\infty$ & $\approx$ & $a$ & $x \operatorname{sen}$ & 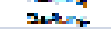 \\
\hline * & a & ה ה & $\eta n$ & $=$ & $\pi$ & $*: *$ & $x+\infty$ \\
\hline $2:$ & $\$$ & 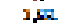 & je & 2 & 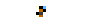 & misos & $\operatorname{Ien}=$ \\
\hline $2 \pi$ & $\pi$ & $52 x$ & s & $x$ & I & $=0$. & Sather: \\
\hline$=\not 6$ & $\pi$ & e.t. & $n$ & $i^{*}$ & 7 & $m$ & 7Wr:C \\
\hline$\rightarrow$ & $\therefore$ & 20 & $x$ & 1 & D & $00 \leq 0$ & Sabery \\
\hline$m$ & $=$ & 5.40 & $s$ & $=$ & 2 & suree & nedier \\
\hline
\end{tabular}

Notasi yang akan digunakan untuk pembahasan selanjutnya adalah :

$\mathrm{Y}=$ Jumlah kecelakaan lalulintas pada suatu ruas/segmen (kecelakaan/tahun)

$\mathrm{X} 1=$ Panjang ruas atau segmen jalan $(\mathrm{m})$

$\mathrm{X} 2=$ Lebar perkerasan jalan $(\mathrm{m})$

X3 = Variabel dummy untuk median, 1 untuk jalan tanpa median dan 0 untuk jalan yang dilengkapi median

X4= Jumlah simpang yang tidak dilengkapi lampu lalulintas pada ruas/segmen yang bersangkutan.(bh)

$\mathrm{X} 5=$ Volume lalulintas harian rata-rata tahunan (kendaraan/hari)

X6= Variabel dummy untuk hambatan samping, 1 untuk tinggi s.d tinggi sekali, dan 0 untuk rendah s.d sedang

Persamaan dan besaran-besaran yang diperlukan diselesaikan dengan menggunakan program SPSS 11.5 for Windows.

\subsection{Pembentukan Model Prediksi Kecelakaan Lalulintas}

Pada tahap awal, data yang digunakan untuk menyusun modal regresi adalah data kecelakaan lalulintas, geometrik dan lingkungan pada 19 ruas jalan, yang diuraikan lagi menjadi 45 segmen. Data dapat dilihat pada Tabel 2.

Metode yang digunakan untuk pembuatan model regresi adalah metode stepwise. Sehubungan hal tersebut maka uji signifikansi model (uji t, uji f, dsb) mendahului uji asumsi model regresi (uji multikoleneritas, normalitas, dsb)

Metode stepwise dilakukan dengan langkah menggunakan seleksi secara bertahap. Misalkan variabel bebas yang pertama masuk kedalam model ialah X1 (misalkan b1 $\neq 0$ ), diikuti kemudian oleh X2. Misalkan setelah diuji, $\mathrm{b} 2 \neq 0$ setelah X1 masuk terlebih dahulu. Pada tahap ini, dengan menggunakan metode penyisihan ingin dipertanyakan apakah setelah variabel X2 masuk, pengaruh variabel X1 masih berarti. Jadi pada metode ini, pada tiap tahap selalu dipertanyakan apakah suatu variabel yang telah masuk kedalam model masih perlu dipertahankan atau sebaiknya keluar. Jika sekiranya pengaruh variabel X1, setelah variabel X2 masuk tidak berarti, maka variabel X1 dikeluarkan dari model, dan sebaliknya maka variabel X1 boleh dimasukan dalam model sampai pengujian tahap berikutnya. 
Tahapan selanjutnya adalah menyeleksi variabel berikutnya yang akan dimasukan kedalam model, misalkan X3 dan misalkan pula pengaruhnya berarti. Kembali gunakan metode penyisihan untuk menguji apakah variabel X1 dan X2 masih tetap tinggal atau harus keluar dari model. Begitu selanjutnya secara bergantian kedua tahap digunakan sampai selesai.

Metode Stepwise dapat langsung dikerjakan dengan menggunakan program komputer SPSS 11.5 for Windows. Tabel 4 memperlihatkan proses pemasukan dan penyisihan variabel bebas dalam model regresi. Suatu variabel akan disisihkan dalam model apabila memiliki p-value (angka probabilitas) yang lebih besar dari tingkat signifikansi yang ditetapkan, dalam hal ini 0,05 dan mempunyai angka toleransi mendekati angka satu. Dari tabel tersebut terlihat ada dua buah model persamaan regresi yang dihasilkan. Model pertama memperlihatkan hubungan jumlah kecelakaan $(\mathrm{Y})$ dengan satu variabel bebas, yaitu jumlah simpang tanpa lampu lalulintas (X4) sedangkan model kedua menunjukan bahwa jumlah kecelakaan (Y) cukup signifikan dipengaruhi oleh jumlah simpang tanpa lampu lalulintas (X4) dan lebar jalan (X2).

Tabel 4 Penyisihan Variabel Bebas pada Metode stepwise

\begin{tabular}{|c|c|c|c|c|c|c|}
\hline \multirow{2}{*}{\multicolumn{2}{|c|}{$N_{t}+d y$}} & \multirow[b]{2}{*}{ بex h } & \multirow[b]{2}{*}{1} & \multirow[b]{2}{*}{ Sic } & \multirow{2}{*}{$\begin{array}{c}\text { Arrial } \\
\text { corectung }\end{array}$} & \multirow{2}{*}{ 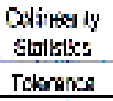 } \\
\hline & & & & & & \\
\hline \multirow[t]{5}{*}{1} & $\overline{x_{i}}$ & SC:C & 2.115 & .QSO & .910 & $\Delta x$ \\
\hline & $\sigma$ & .2 .16 & 2479 & 6,7 & $.35 i$ & $\$ 1$ \\
\hline & $\mathrm{x}$ & 141 & 1.292 & 174 & .208 & .999 \\
\hline & $x ;$ & 60 & -621 & 362 & .141 & .96 \\
\hline & $x_{n}$ & revi & .211 & 50 & -.093 & 285 \\
\hline \multirow[t]{4}{*}{2} & $\mathrm{xi}$ & 217 & $1: 1 /$ & .131 & .296 & $.0 \% 5$ \\
\hline & $x 3$ & $i^{4} 5$ & .214 & 010 & wet &.$H C S$ \\
\hline & $x_{5}$ & -0.1 & -175 & 90 & $-.52]$ & .853 \\
\hline & $x_{3}$ & 024 & E & s1s & $-[2]$ & 5: \\
\hline
\end{tabular}

- Aveticlar je jeresma, $x_{4}$

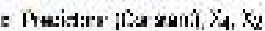

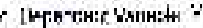

Hasil analisis kolerasi dari model yang diperoleh dengan metode Stepwise dapat dilihat pada Tabel 5 kedua model regresi masing-masing memiliki koefisien korelasi sebesar 0,725 dan 0,766 dengan demikian dapat dikatakan bahwa model yang terbaik adalah model kedua, yaitu model yang mempunyai koefisien kolerasi terbesar $(0,766)$ artinya korelasi linier atau derajat hubungan antara jumlah kecelakaan lalulintas (Y) dengan variabel $\mathrm{X} 4$ dan $\mathrm{X} 2$ adalah cukup kuat, yaitu sebesar 76,6 \% angka $\mathrm{R}$ square atau koefisien determinasi untuk model kedua adalah 0,587 hal ini berarti 58,7 \% variasi jumlah kecelakaan lalulintas (Y) bisa dijelaskan oleh variasi dari kedua variabel bebas.

Tabel 5 Keseluruhan Analisis Kolerasi

\begin{tabular}{|l|r|r|r|r|r|}
\hline Model & $R$ & $R$ Square & $\begin{array}{c}\text { Adjusted R } \\
\text { Squate }\end{array}$ & $\begin{array}{r}\text { Sid. Emor of } \\
\text { the Estinate }\end{array}$ & $\begin{array}{r}\text { Durtin- } \\
\text { Watson }\end{array}$ \\
\hline 1 & $725^{4}$ & .526 & 515 & 8.52944 & \\
\hline 2 & $.766^{5}$ & .587 & 567 & 8.06091 & 1.718 \\
\hline
\end{tabular}

a Predictors: (Constant), $X_{4}$

b Predictors: (Constant), $X_{4}, X_{2}$

c. Dependent Variable; Y

Hasil uji simultan model regresi adalah seperti pada Tabel 6. Pada model pertama, dengan variabel yang mempengaruhi model regresi adalah jumlah simpang tanpa lampu lalulintas (X4), diperoleh angka signifikan (p-value) sebesar 0,00 angka tersebut masih dibawah tingkat signifikansi yang ditentukan yaitu 0,05 maka variabel bebas berpengaruh terhadap nilai variabel tidak bebas. Demikian juga pada model kedua dengan variabel bebas jumlah simpang tanpa lampu lalulintas (X4) dan lebar jalan (X2) menghasilkan angka signifikan ( $\mathrm{p}$-value) sebesar 0,00 angka tersebut masih dibawah tingkat signifikansi yang ditentukan yaitu 0,05 dengan demikian variabel bebas berpengaruh terhadap variabel tidak bebas.

Tabel 6 Keluaran Uji Simultan

\begin{tabular}{|c|c|c|c|c|c|c|}
\hline Noces & & $\begin{array}{l}\text { Eun of } \\
\text { SB.IA }\end{array}$ & 이 & Magn Stuate & $F$ & Sig. \\
\hline \multirow[t]{3}{*}{1} & Fegression & 2672.483 & 1 & 3472.493 & 47,731 & $200 \%$ \\
\hline & Residual & 31283.4 & 4.3 & $\quad 72.751$ & & \\
\hline & Total & $6600.80^{\circ}$ & 41 & 1 & & \\
\hline \multirow[t]{3}{*}{2} & Foğiqkèizo. & sina.7is & $i$ & 180,000 & $29.78 \%$ & $\cos ^{h}$ \\
\hline & Residual & 2729.069 & 12 & B4.970 & & \\
\hline & 7018 & $\sin 8 x$ & 4 & & & \\
\hline \multicolumn{7}{|c|}{ Padecers (ansian), $X_{4}$} \\
\hline \multicolumn{7}{|c|}{$\begin{array}{l}\text { b Preders: (Constanti, } X_{4}, X_{2} \\
\text { c Dependen Variable: } Y\end{array}$} \\
\hline
\end{tabular}

Koefisien persamaan model regresi pada Tabel 7. Uji $t$ dilakukan untuk menguji signifikansi konstanta dan semua variabel bebas dalam model regresi. Pada model pertama, yaitu $\mathrm{Y}=-2,947+$ 3,282 X4, koefisien regresi menghasilkan pvalue sebesar 0,00. Angka tersebut lebih kecil dari tingkat signifikansi yang ditetapkan yaitu 0,05 , berarti jumlah simpang tanpa lampu lalulintas (X4) mempengaruhi model kedua, 
yaitu, $\mathrm{Y}=9,756+3,439 \mathrm{X} 4-1,162 \mathrm{X} 2$ koefisien regresinya masing-masing menghasilkan $\mathrm{p}$-value sebesar 0,00. Angka tersebut lebih kecil dari tingkat signifkansi yang ditetapkan yaitu 0,05 , berarti jumlah simpang tanpa lampu lalulintas (X4) dan lebar jalan (X2) mempengaruhi model.

Tabel 7 Keluaran Koefisien Persamaan Regresi

\begin{tabular}{|c|c|c|c|c|c|c|}
\hline \multirow[b]{2}{*}{$x=0$} & & \multicolumn{2}{|c|}{ 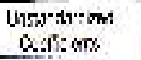 } & \multirow{2}{*}{ 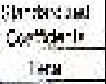 } & \multirow[b]{2}{*}{$\therefore$} & \multirow[b]{2}{*}{ Eh } \\
\hline & & 3 & 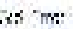 & & & \\
\hline & ":ints in & $87 i$ & $20 ! 2$ & & 3.54 & $I R$ \\
\hline & $x_{1}$ & 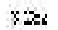 & 4: & $1 \%$ & sis &.$\omega$ \\
\hline$i$ & I"mess-1 & $\overline{6} \div \cdot \div$ & $\therefore 43$ & & $1 . .82$ & .00 \\
\hline & 86 & II & $t: 2$ & .60 & $\because n^{*}$ & : an: \\
\hline & Ki & $-1.19 \mathrm{i}$ & $4: 0$ & - $\times$ ! & $\therefore 6 \%$ & Mi \\
\hline
\end{tabular}

Selanjutnya terhadap model regresi terbaik yang telah diuji signifikansinya yaitu $=9,756+3,439$ - 1,162 X2, dilakukan uji asumsi regresi linear berganda. Uji asumsi tersebut meliputi heteroskedatisitas, autokorelasi, multikolinearitas dan normalitas.

Model regresi yang baik adalah tidak terjadi heteroskedatisitas. Menguji adanya heteroscedaticty dapat dilakukan dangan mengkaji diagram sebaran nilai residual model regresi, seperti yang terlihat pada Gambar 2. Diagram tersebut merupakan keluaran program SPSS 11.5 for Windows untuk menguji adanya heteroskedatisitas.

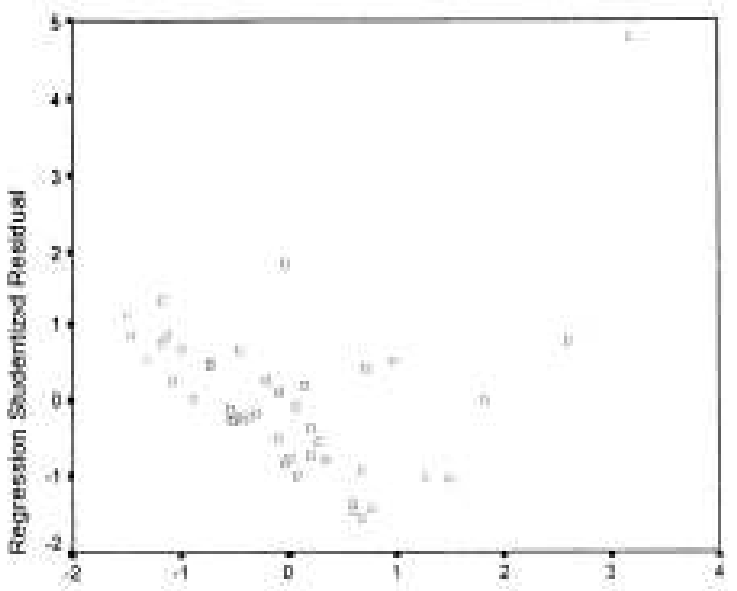

Regression Standardized Precicled Vaiue

Gambar 2 Diagram Uji Heteroskedatisitas

Pada gambar 2, terlihat bahwa titik-titik melebar secara acak, tidak membentuk pola tertentu yang jelas, serta terbesar di atas maupun di bawah angka nol pada sumbu Y. Hal ini menunjukan tidak terjadi heteroskedatisitas pada model regresi.
Untuk mengetahui adanya autokorelasi digunakan statistik Durbin-Watson. Dari keluaran program SPSS 11,5 diperoleh nilai statistik Durbin-Watson sebesar 1,718, seperti yang terlihat pada Tabel 5 dan apabila dibandingkan dengan Tabel statistik DurbinWatson untuk 2 variabel bebas dan 45 seri data yang bernilai antara 1,33 sampai dengan 1,58, maka nilai statistik Durbin-Watson yang diperoleh dari perhitungan jatuh di daerah 1,58< $\mathrm{d}$ hitung $<(4-1,58=2,42)$ sehigga dapat diartikan tidak terjadi autokorelasi pada model regresi.

Uji multikolineritas untuk menguji apakah pada model regresi ditemukan adanya korelasi antar variabel bebas. Model regresi yang baik seharusnya tidak terjadi multikolinieritas. Tabel 8 adalah keluaran program SPSS1.5 untuk uji multikolinieritas.

Tabel 8 Keluaran Uji Multikolinieritas

\begin{tabular}{|c|c|c|c|}
\hline \multirow{2}{*}{\multicolumn{2}{|c|}{ Made! }} & \multicolumn{2}{|c|}{ Collinearil: Stalislics } \\
\hline & & Tolerance & ViF \\
\hline 1 & $x 4$ & $9, \mathrm{CCC}$ & .000 \\
\hline 2 & $\overline{x 4}$ & .901 & .070 \\
\hline & $x_{2}$ & sa1 & .026 \\
\hline
\end{tabular}

Pada Tabel 8 terlihat untuk kedua variabel bebas, Angka VIF ada sekitar angka satu. Demikian juga toleransi mendekati angka satu. Dengan demikian pada model regresi tersebut tidak terdapat problem multikolinieritas.

Untuk menguji apakah dalam model regresi, variabel tidak bebas dan variabel bebas mempunyai distribusi normal dilakukan uji normalitas. Hasil uji normalitas dengan menggunakan program SPSS 11.5 ditunjukan pada gambar 3 .

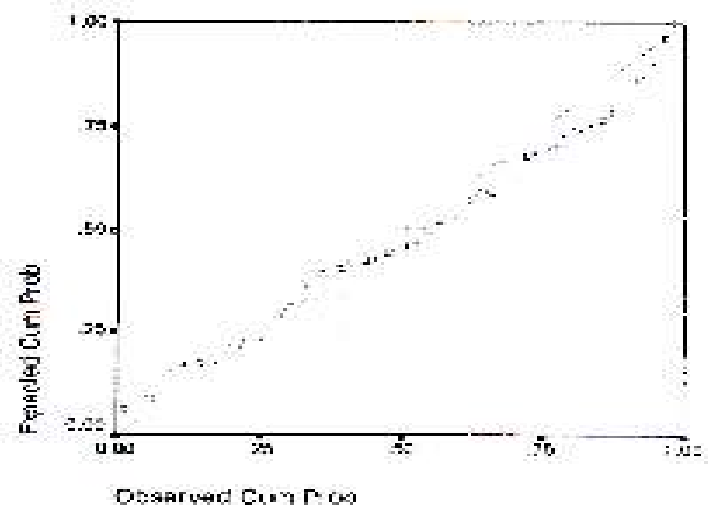


Gambar 3 Uji Normalitas.

Pada Gambar 3 terlihat titik-titik menyebar disekitar garis diagonal, serta penyebaran mengikuti arah garis diagonal. Dengan demikian dapat diartikan semua variabel pada model regresi mempunyai data dengan distribusi normal.

Dari uraian uji signifikansi dan uji asumsi di atas, terlihat bahwa model regresi yang dihasilkan, yaitu $\mathrm{Y}=9,756+3,439 \mathrm{X} 4-1,162 \mathrm{X} 2$, talah memenuhi uji signifikan dan memenuhi asumsi model regresi linier sehingga persamaan tersebut layak untuk dipakai untuk prediksi kecelakaan lalulintas berdasarkan masukan variabel bebasnya.

\subsection{Validasi Silang Model Regresi}

Setelah mendapatkan model regresi terbaik, langkah selanjutnya adalah memastikan bahwa model tersebut mewakili populasi lainnya. Pada tahap validasi silang ini digunakan kelompok data yang berbeda dengan kelompok data yang digunakan untuk membuat model regresi. Kelompok data ini terdiri atas 14 ruas jalan yang kemudian dipecah lagi menjadi 41 segmen. Data dapat dilihat pada Tabel 3.

Proses validasi silang model regresi dilakukan dengan langkah melompatkan jumlah kecelakaan berdasarkan data lapangan dan hasil perhitungan model regresi yang dihasilkan, yaitu $\mathrm{Y}=9,756+$ 3, 439 X4 - 1,162 X2 dan dilihat penyebarannya terhadap garis diagonal. Garis diagonal dengan sudut 45 derajat adalah garis yang menunjukan data jumlah kecelakaan di lapangan sama dengan hasil perhitungan model regresi. Gambar 4 memperlihatkan titik-titik menyebar di atas dan dibawah garis diagonal. Berdasarkan hasil tersebut dapat disimpulkan model regresi yang dihasilkan cukup mewakili seluruh populasi.

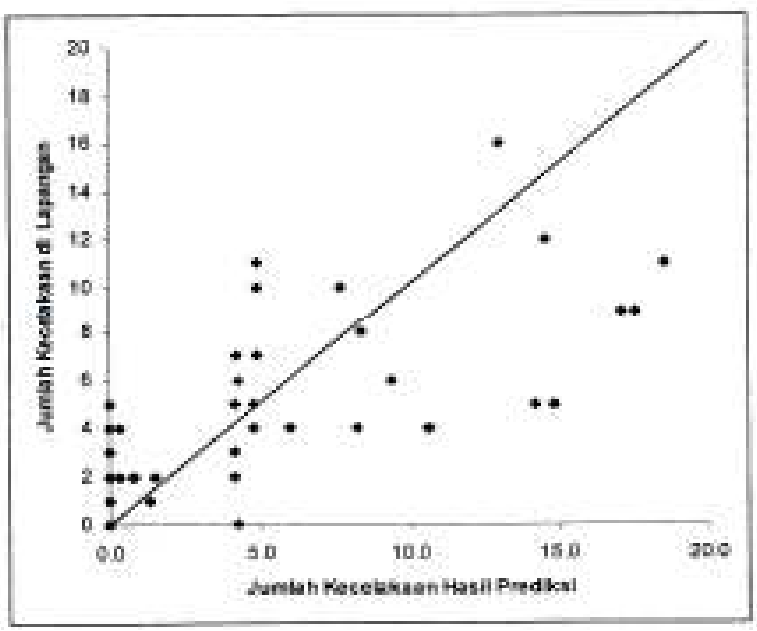

Gambar 4 Penyebaran Data Jumlah Kecelakaan Berdasarkan Hasil Validasi Silang.

Dari pembahasan di atas didapat bahwa jumlah kecelakaan lalulintas pada ruas jalan di kota Bandung sangat dipengaruhi oleh variabel jumlah simpang tanpa lampu lalulintas pada ruas jalan yang bersangkutan (X4) dan lebar (X2). Dari model regresi yang dihasilkan yaitu $\mathrm{Y}=$ $9,756+3,439$ X4 - 1,162 X2 terlihat bahwa semakin besar jumlah simpang tanpa lampu lalulintas pada ruas jalan yang bersangkutan akan meningkatkan jumlah kecelakaan lalulintas. Pada jalan yang lebih lebar, jumlah kecelakaan lalulintas cenderung menurun.

\subsection{Penggunaan Tingkat Kecelakaan Sebagai Variabel Tidak Bebas.}

Pengembangan model prediksi kecelakaan yang diuraikan diatas menghasilkan hubungan antara kecelakaan lalulintas dengan dua variabel geometrik jalan, yaitu lebar jalan dan jumlah simpang tanpa lampu lalulintas. Sementara variabel geometrik dan lingkungan jalan lainnya yang dikaji, yaitu panjang segmen jalan, LHRT, median, dan hambatan samping tidak cukup signifikan mendasari terjadinya kecelakaan lalulintas. Sebagai upaya pengembangan model regresi yang menghubungkan kecelakaan lalulintas dengan lebih banyak variabel geometrik dan lingkungan jalan, terutama variabel volume lalulintas, maka dicoba dilakukan perubahan penggunaan variabel tidak bebas dari jumlah kecelakaan lalulintas menjadi tingkat kecelakaan lalulintas (accident rate). Data yang digunakan untuk pembentukan model regresi dapat dilihat pada Tabel 9. 
Tabel 9.

Data

Hubungan

Tingkat

Kecelakaan Dengan Geometrik dan Lingkungan Jalan Untuk Pembentukan Model Regresi.

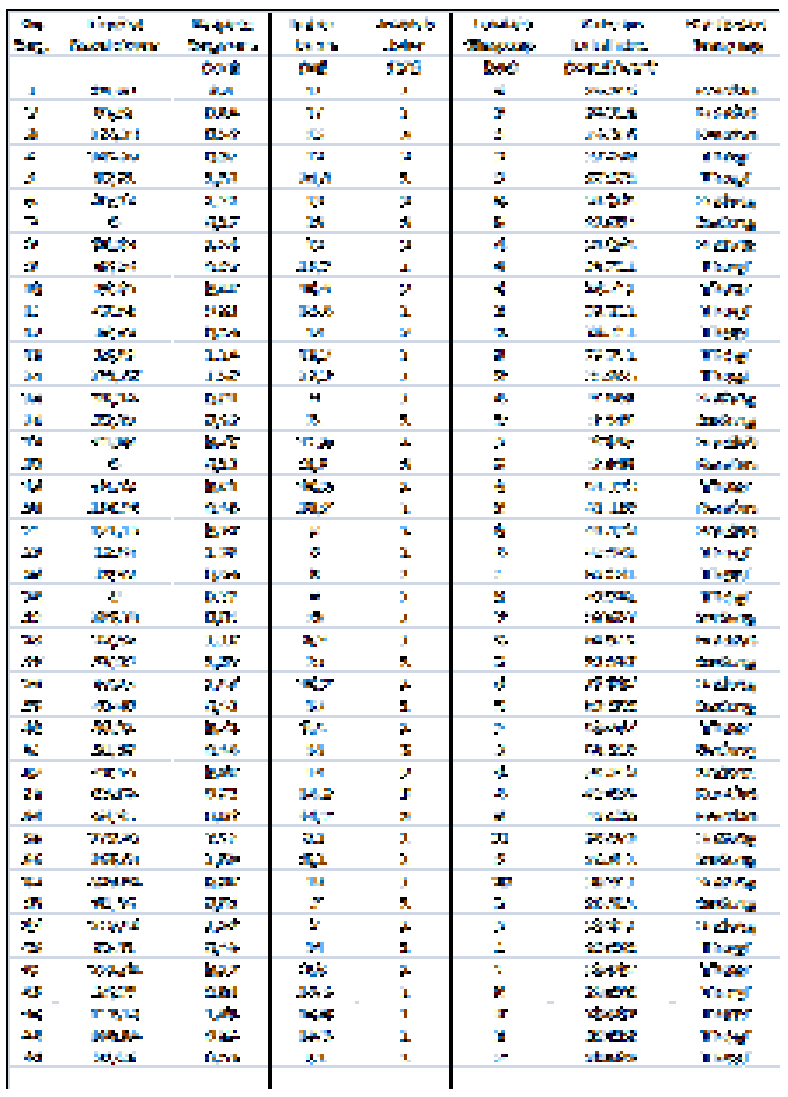

Metode yang digunakan untuk pembuatan model regresi adalah metode Stepwise. Metode stepwise dikerjakan dengan menggunakam program komputer SPSS 11.5 for windows. Tabel 10 memperlihatkan proses pemasukan dan penyisihan variabel bebas dalam model regresi. Satu variabel akan disisihkan dalam model apabila memiliki p-value (angka probabilitas) yang lebih besar dari tingkat signifikansi yang ditetapkan, dalam hal ini 0,05 dan mempunyai angka toleransi mendekati angka satu. Dari tabel tersebut terlihat dua buah model persamaan regresi yang dihasilkan. Model pertama memperlihatkan hubungan tingkat kecelakaan lalulintas (Y) dengan satu variabel bebas, yaitu jumlah simpang tanpa lampu lalulintas (X4), sedangkan model kedua menunjukan bahwa tingkat kecelakan (Y) cukup signifikan dipengaruhi oleh jumlah simpang tanpa lampu lalulintas (X4) dan LHRT (X5).

Tabel 10. Penyisihan Variabel Bebas Pada Metode Stepwise Dengan Tingkat Kecelakaan Sebagai Variabel Tidak Bebas

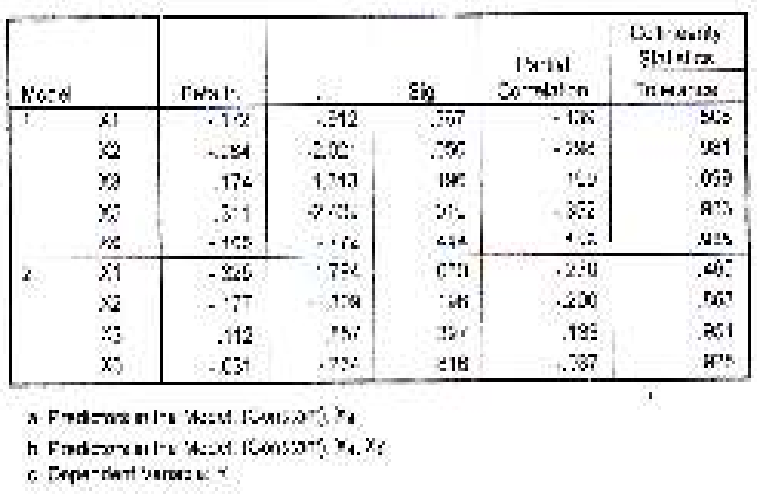

Hasil analisis korelasi model yang diperoleh dengan metode Stepwise dapat pada Tabel 11. Kedua model regresi masing-masing memiliki koefisien kolerasi sebesar 0,480 dan 0,571. Dengan demikian dapat dikatakan bahwa model yang terbaik adalah model kedua, yaitu model yang mempunyai koefisien korelasi terbesar $(0,571)$, artinya kolerasi linier atau derajat hubungan antara kecelakaan lalulintas (Y) dengan variabel X4 dan X5 adalah cukup kuat, yaitu sebesar 57,1\%. Angka $\mathrm{R}$ squaire atau koefisien determinasi untuk model kedua adalah 0,326 , hal ini berarti $32,6 \%$ variasi dari variabel bebas.

Tabel 11 Keluaran Analisis Korelasi Dengan Tingkat Kecelakaan Sebagai Variabel Tidak Bebas.

\begin{tabular}{|c|c|c|c|c|c|}
\hline Model & $R$ & $R$ Squares & $\begin{array}{l}\text { Adjusted R } \\
\text { Scuare }\end{array}$ & $\begin{array}{l}\text { Sid. Error of } \\
\text { he Estionate }\end{array}$ & $\begin{array}{l}\text { Dutin. } \\
\text { Watson }\end{array}$ \\
\hline 1 & $.480^{7}$ & .231 & .213 & 796460 & \\
\hline 2 & $.577^{\mathrm{t}}$ & .325 & 294 & 75.61028 & 1.721 \\
\hline
\end{tabular}

a Predicters: (Constanti $X_{4}$

- Frediclars. (Constan)) $X_{4}, X_{5}$

c. Dependent Veriable: Y

Hasil ujian simultan model regresi adalah seperti pada Tabel 12. Pada model pertama, dengan variabel yang mempengaruhi model regresi adalah jumlah simpang tanpa lampu lalulintas (X4), diperoleh angka signifikan ( $p$-value) sebesar 0,001. Angka tersebut masih di bawah tingkat signifikansi yang ditentukan yaitu 0,05 , maka variabel bebas X4 berpengaruh terhadap nilai variabel tidak bebas. Demikian juga pada model kedua dengan variabel bebas jumlah simpang tanpa lampu lalulintas (X4) dan LHRT (X5), menghasilkan angka signifikan (p-value) sebesar 0,000. Angka tersebut masih dibawah tingkat signifikansi yang ditentukan yaitu 0,05 , 
dengan demikian variabel bebas X4 dan X5 berpengaruh terhadap nilai variabel tidak bebas.

Tabel 12 Keluaran Uji Simultan Dengan Tingkat Kecelakaan Sebagai Variabel Tidak Bebas

\begin{tabular}{|c|c|c|c|c|c|c|}
\hline inz & & 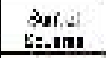 & $r$ & 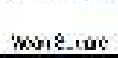 & $r$ & $\sin$ \\
\hline \multirow[t]{3}{*}{1} & Paptod:- & $k$ in & $\therefore$ & 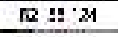 & $17 \mathrm{rT}$ & $w: 1^{2}$ \\
\hline & $205=1 . x$ & $2 i 4131.24$ ! & 42 & 4: & & \\
\hline & Ien & 2t:ite.s: & 14 & & & \\
\hline \multirow[t]{3}{*}{3} & Rupistor & 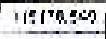 & 2 & 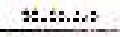 & 6. & $\ldots v^{2}$ \\
\hline & 2) $6: d$ & 24:116izu & 42 & :TIi, Ban & & \\
\hline & $1 \times 2$ & 2128:4 & 2 & & & \\
\hline
\end{tabular}

Koefisien persamaan model regresi dapat dilihat pada Tabel 13. Uji t dilakukan untuk menguji signifikansi konstanta dan semua variabel bebas dalam model regresi. Pada model pertama, yaitu $\mathrm{Y}=32,169+15,965 \mathrm{X} 4$, koefisien regresi menghasilkan p-value sebesar 0,001. Angka tersebut lebih kecil dari tingkat signifikansi yang ditetapkan yaitu 0,05 , berarti jumlah simpang tanpa lampu lalulintas (X4) mempengaruhi model. Pada model kedua, yaitu Y $=78,031+17,195 \quad \mathrm{X} 4 \quad-0,002 \quad \mathrm{X} 5$, koefisien regresinya masing-masing menghasilkan $\mathrm{p}$-value sebesar 0,000 dan 0,019. Angka tersebut lebih kecil dari tingkat signifikansi yang ditetapkan yaitu 0,05 , berarti jumlah simpang tanpa lampu lalulintas (X4), dan LHRT (X5) mempengaruhi model.

Tabel 13 Keluaran Koefisien Persamaan Regresi Dengan Tingkat Kecelakaan Sebagai Variabel Tidak Bebas

\begin{tabular}{|c|c|c|c|c|c|c|}
\hline \multirow[b]{2}{*}{ Mece } & & \multicolumn{2}{|c|}{$\begin{array}{l}\text { Uryturdscized } \\
\text { Costlicents }\end{array}$} & \multirow{2}{*}{ 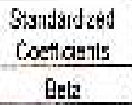 } & \multirow[b]{2}{*}{1} & \multirow[b]{2}{*}{50} \\
\hline & & $\mathrm{b}$ & Stc. Err & & & \\
\hline & |Cansant) & 32.156 & $18.6 E 8$ & & 1 积: & $09 \mathrm{j}$ \\
\hline & $x_{4}$ & 15895 & 4,447 & 460 & $3.5 \pm[$ & $\mathrm{Oj}_{\mathrm{i}}$ \\
\hline \multirow[t]{3}{*}{ ! } & (C) & 78031 & 7: CED & & 2 & 095 \\
\hline & $x_{1}$ & 17135 & $4.24 z$ & $.51 \%$ & L.UEd & 030 \\
\hline & $\mathrm{X}:$ & .342 & $\hat{.0 .}$ & -311 & $.2<38$ & 018 \\
\hline
\end{tabular}

a. [efendem Wratu:?

Selanjutnya terhadap model regresi terbaik yang sudah diuji signifikansinya, yaitu $\mathrm{Y}=$ 78,31+17,195 X4 - 0,002 X5, dilakukan uji asumsi regresi linear berganda. Uji asumsi tersebut meliputi uji heteroskedatisitas, autokorelasi, multikolinearitas dan normalitas.
Model regresi yang baik adalah tidak terjadi heteroskedatisitas, mengkaji adanya heteroscedaticity dapat dilakukan dengan mengkaji diagram sebaran nilai residual model regresi, seperti yang terlihat pada gambar 5 . Diagram tersebut merupakan keluaran program SPSS 11.5 for Window untuk menguji heteroskedatisitas.

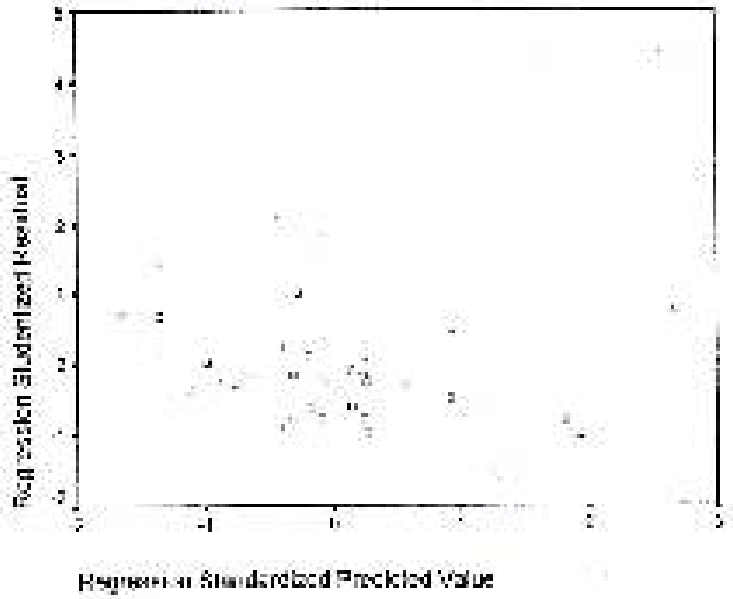

Gambar 5. Diagram Uji Heteroskedatisitas Dengan Tingkat Kecelakaan Sebagai Variabel Tidak Bebas

Pada Gambar 5, terlihat bahwa titk-titik menyebar secara acak, tidak membentuk pola tertentu yang jelas serta tersebar diatas maupun di bawah angka nol pada sumbu Y. Hal ini menunjukan tidak terjadinya heteroskedatisitas pada model regresi.

Untuk mengetahui adanya autokolerasi digunakan statistik Durbin-Watson dari keluaran keluaran program SPSS 11.5 diperoleh nilai statistik Durbin-Watson sebesar 1,721, seperti yang terlihat pada Tabel 11 dan apabila dibandingkan dengan Tabel statistik DurbinWatson untuk 2 variabel bebas dan 45 seri data yang bernilai 1,33 sampai dengan 1,85 maka nilai statistik Durbin-Watson yang diperoleh dari perhitungan jauh di daerah $<\mathrm{d}$ hitung $<(4-1,58=$ $2,42)$ sehingga dapat diartikan tidak terjadi autokolerasi model regresi.

Uji multikolinieritas dilakukan untuk menguji apakah pada model regresi ditemukan adanya kolerasi antar variabel bebas. Model regresi yang baik seharusnya tidak terjadi multikolinieritas. Tabel 14 adalah keluaran program SPSS 11.5 untuk uji multikolinieritas. 
Tabel 14 Keluaraan Uji multikolinieritas Dengan Tingkat Kecelakaan Sebagai Variabel Tidak Bebas

\begin{tabular}{|c|c|c|c|}
\hline \multirow{2}{*}{\multicolumn{2}{|c|}{ |AOAnI }} & \multicolumn{2}{|c|}{ Colinesrs: Sintiatis: } \\
\hline & & Tolarance & VIF \\
\hline 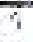 & $\times 4$ & $\operatorname{dox}$ & 900 \\
\hline 2 & $x .4$ & .966 & $\cdot 614$ \\
\hline & $x s$ & $.9: 6$ & $-5: 4$ \\
\hline
\end{tabular}

a. Lesardant ber ats: $\gamma$

Pada Tabel 14 terlihat untuk kedua variabel bebas, angka VIF ada disekitar angka satu. Demikian juga toleransi mendekati angka satu. Dengan demikian pada model regresi tersebut tidak terdapat problem multikolinieritas.

Untuk menguji apakah dalam model regresi, variabel tidak bebas dan variabel bebas mempunyai distribusi normal, dilakukan uji normalitas. Hasil uji normalitas dengan mengunakan program SPSS 11.5 ditunjukan pada Gambar 6.

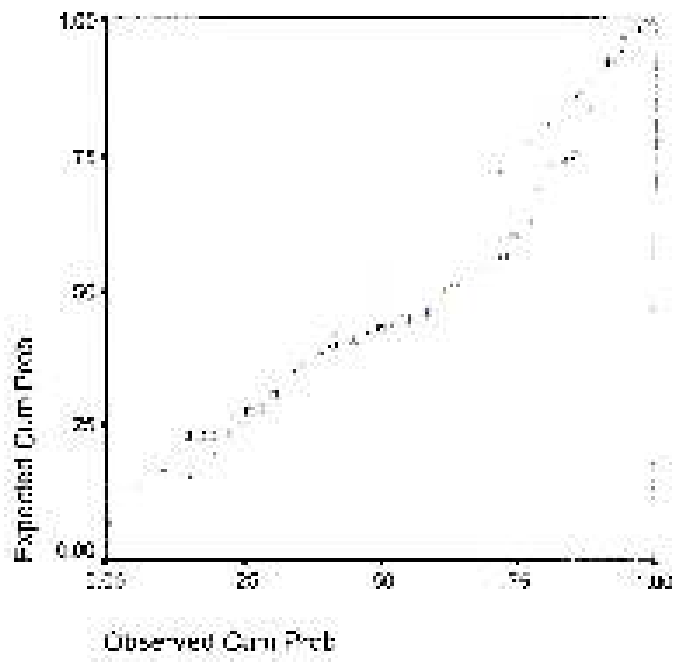

Gambar 6 Uji Normalitas

Dengan Tingkat Kecelakaan Sebagai Variabel Tidak Bebas

Pada gambar 6 terlihat titik-titik menyebar disekitar garis diagonal, serta penyebaran mengikuti arah garis diagonal. Dengan demikian dapat diartikan semua variabel pada model regresi mempunyai data dengan distribusi normal.

Dari uraian uji signifikansi dan uji asumsi di atas, terlihat bahwa model regresi yang dihasikan, yaitu $\mathrm{Y}=78,031+17,195 \mathrm{X} 4-0,002 \mathrm{X} 5$, telah memenuhi uji signifikansi dan memenuhi asumsi model regresi linier sehingga persamaan tersebut layak untuk dipakai untuk prediksi kecelakaan lalulintas berdasarkan masukan variabel bebasnya.

Setelah mendapat model regresi terbaik, langkah selanjutnya adalah memastikan bahwa model tersebut mewakili populasi lainnya. Pada tahap validasi silang ini digunakan kelompok data yang berbeda dengan kelompok data yang digunakan untuk membuat model regresi. Kelompok data ini terdiri dari 14 ruas jalan yang kemudian dipecah lagi menjadi 41 segmen. Data dapat dilihat pada Tabel 15

Tabel 15. Data Hubungan Tingkat Kecelakaan Dengan Geometrik dan Lingkungan Jalan untuk Validasi Silang.

\begin{tabular}{|c|c|c|c|c|c|c|c|}
\hline $7 x$ & $\begin{array}{l}\text { 1.tation } \\
\text { rentions }\end{array}$ & 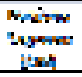 & 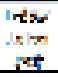 & 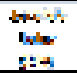 & $\begin{array}{l}\text { and } \\
\text { swoes } \\
\text { wat }\end{array}$ & $\begin{array}{c}\text { Wrat } \\
\text { uteww: } \\
\text { betemi }\end{array}$ & t:abdwo \\
\hline 3 & $x, z$ & $2 x$ & $\sin$ & 1 & 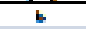 & 3000 & $\operatorname{son}_{1} x i \operatorname{ind}$ \\
\hline 7 & 70 & $5: x$ & $x y^{\prime}$ & 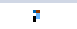 & $\because$ & $" ; u=x$ & 16xtains \\
\hline 6 & בת & $3 \neq h$ & $13 \pi$ & 2 & a & 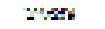 & 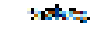 \\
\hline$b$ & $a=$ & $\Rightarrow$ & 136 & $\approx$ & $s$ & $A 5 x$ & Jumag \\
\hline$\rightarrow$ & "מר & at & 22 & $i$ & 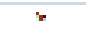 & 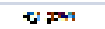 & $\ln 4 \pi \infty$ \\
\hline$<$ & $\pi x i$ & ה.1 & $x .2$ & 2 & 1 & $x$ in & $\ln x$ \\
\hline 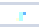 & $\infty 00,01$ & $a \cdot 1$ & $\operatorname{Ien}$ & 7 & $?$ & $<1 . \approx 1$ & $m=r:$ \\
\hline$=$ & $\sin x$ & Ex & 377 & $x$ & " & nat & 124 \\
\hline 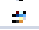 & ivs & $\Rightarrow$ & $8 \%$ & 8 & 2 & $\operatorname{ses} 3$ & $\cos x$ \\
\hline 4 & and & $=$ & $A y$ & 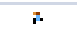 & $\eta^{\prime}$ & $\sin x$ & $x=2$ \\
\hline 13 & $\boldsymbol{\Psi}=\mathrm{x}$ & $n 32$ & is & 4 & 2 & . & $\operatorname{sen} 0^{\circ}$ \\
\hline to & $m>b$ & 5,85 & $\$ 6$ & 2 & 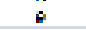 & stes: & seiken \\
\hline$x=$ & wen & "משs" & $\pi$ & ' & 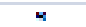 & 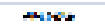 & acts \\
\hline .21 & 1,00 & 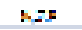 & $x$ & $=$ & $s$ & sects & sereres \\
\hline$\omega$ & Nos & $-\pi$ & $\eta$ & $\gamma$ & - & \$NO & 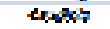 \\
\hline$n$ & Th & مع & $\boldsymbol{x}$ & 2 & a. & $\$ 74$ & $7 e=n$ \\
\hline It & 3.4 & Yl & $*$ & 8 & $s$ & 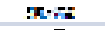 & Serotaxe \\
\hline$=$ & $4 x:$ & 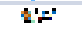 & $\pi$ & $\therefore$ & $>$ & $\because \pi$ & noker \\
\hline at & tus & $\therefore a$ & er & - & a & aent & 3athes \\
\hline$\approx$ & - & $\$$ & $c_{2}$, & $i$ & 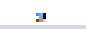 & mest & lat? \\
\hline ב & $+\infty$ & ej: & קز & $x$ & $x$ & 7anes & nes \\
\hline$=$ & ה & $=13$ & 13 & s. & 3 & $2 x-1$ & $\operatorname{rin}:$ \\
\hline 73 & $\because \approx \theta$ & Ats & 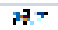 & $z$ & 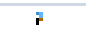 & inen & $\operatorname{lin}^{\prime} \rightarrow$ \\
\hline je & $x+2$ & ת. & $w_{1} 1$ & 2 & 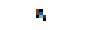 & אים & sntes: \\
\hline$\therefore$ & $=$ & 0,2 & 196 & 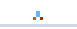 & ¿. & קטב & Ewherg \\
\hline 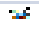 & nur & a) & 245 & 2 & n & 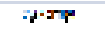 & 140 \\
\hline$=5$ & o & $x=$ & $230^{\circ}$ & 1 & 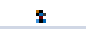 & 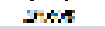 & rote: \\
\hline$x$ & 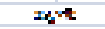 & $n \rightarrow 1$ & 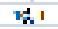 & 1 & .1 & $\operatorname{sen} \alpha$ & nas: \\
\hline$x$ & wyck & 8,80 & ירי & 2 & 3 & X以 & mis' \\
\hline$\Rightarrow$ & 으 & 30 & $\therefore$ & $z$ & 3 & $s<x$ & senter. \\
\hline ta & '; & $\Delta F$ & v: & 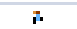 & $\bar{n}$ & 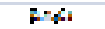 & ห่าผะท \\
\hline is & whe & $\therefore 2$ & $x$ & $z$ & 2 & $b-c_{1}$ & singe \\
\hline$\Delta$ & $m$ a u & נוג2 & w & $z$ & 2 & ans & sendvite \\
\hline "s & ris: & مוه & 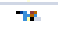 & ' & 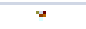 & $\operatorname{sen} \cdot \mathrm{r}$ & $\omega \infty_{\infty}$ \\
\hline 4 & 2 & $\therefore$ & .21 & 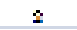 & $=$ & xas & sebers \\
\hline$\not t$ & $n=b$ & $\therefore$ & $m$ & $\gamma$ & $\mathrm{s}$ & thon & whos \\
\hline is & 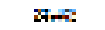 & $\therefore$ & $2 x$ & 2 & $>$ & on $x$ & 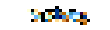 \\
\hline I & $=$ & $8 \pi$ & $M$ & $\approx$ & ⿷ & $p=m$ & sobery \\
\hline$\forall$ & \$144 & $2 \mathrm{~A}$ & $n$ & $\therefore$ & $\because$ & $\sin x$ & Thk:\% \\
\hline At & Hor & 2:14 & $x$ & 2 & a & $\operatorname{sens}$ & Suldos \\
\hline$\infty$ & $p e$ & $\mu$ & $n$ & $\therefore$ & 1 & Exa & nes? \\
\hline
\end{tabular}

Proses validasi silang model regresi dilakukan dengan langkah memplotkan tingkat kecelakaan berdasarkan data lapangan dan hasil perhitungan model regresi yang dihasilkan, yaitu $\mathrm{Y}=78,031$ $+17,195 \mathrm{X} 4-0,002 \mathrm{X} 5$, dan dilihat penyebarannya terhadap garis diagonal. Garis diagonal dengan sudut 45 derajat adalah garis yang menunjukan data tingkat kecelakaan lalulintas dilapangan sama hasil perhitungan 
model regresi. Gambar 7 memperlihatkan titiktitik menyebar di atas dan di bawah garis diagonal. Berdasarkan hasil tersebut dapat diasumsikan model regresi yang dihasilkan cukup mewakili seluruh populasi.

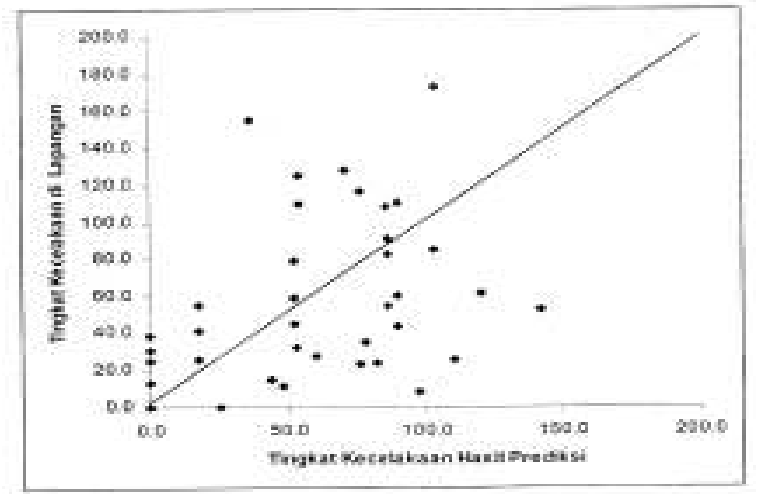

Gambar 7 Penyebaran Data

TingkatKecelakaan

Berdasarkan Hasil Validasi Silang Dari model regresi yang dihasilkan, yaitu $\mathrm{Y}=78,031+$ 17,195 X4 - 0,002 X5, terlihat bahwa tingkat kecelakaan lalulintas di kota Bandung sangat dipengaruhi oleh jumlah simpang tanpa lalulintas dan volume lalulintas (LHRT). Semakin besar jumlah simpang tanpa lampu lalulintas pada suatu segmen jalan akan meningkatkan kecelakaan lalulintas. Pada jalan dengan volume lalulintas lebih tinggi, tingkat kecelakaan cenderung menurun. Menurunnya tingkat kecelakaan tersebut dapat dipahami karena pada segmen jalan dengan volume lalulintas tinggi, kecepatan kendaraan akan lebih rendah. Pada kecepatan yang lebih rendah, tingkat pengendalian pengemudi terhadap kendaraan dan tingkat kewaspadaan terhadap lalulintas sekitar akan lebih baik sehingga peluang terjadi kecelakaan akan lebih kecil.

Model regresi yang diperoleh dengan menggunakan tingkat kecelakaan sebagai variabel tidak bebas, memiliki koefisien korelasi (R) sebesar 0,71 dan koefisien determinasi $\left(\mathrm{R}^{2}\right)$ sebesar 0,326. Besaran tersebut berada dibawah koefisien korelasi dan determinasi dari model regresi dengan menggunakan jumlah kecelakaan sebagai variabel tidak bebas, yaitu koefisien korelasi (R) sebesar 0,766 dan koefisien determinasi $\left(\mathrm{R}^{2}\right)$ sebesar 0,587 .

Model regresi yang baik adalah model yang memiliki koefisien korelasi dan determinasi yang mendekati angka satu serta melibatkan banyak variabel tidak bebas. Karena kedua model regresi, yaitu model dengan variabel tidak bebas berupa jumlah kecelakaan dan tingkat kecelakaan, sama-sama dipengaruhi oleh dua buah variabel bebas, maka yang dijadikan pertimbangan dalam menentukan model regresi terbaik adalah besaran koefisien korelasi dan determinasinya. Berdasarkan pertimbangan tersebut, maka model regresi dengan jumlah kecelakaan sebagai variabel tidak bebas lebih layak digunakan sebagai model prediksi kecelakaan.

\section{Kesimpulan}

Dari hasil analisis statistik dengan metode regresi linier terhadap data kecelakaan lalulintas serta data geometrik dan lingkungan jalan, diperoleh beberapa kesimpulan sebagai berikut :

1. Kecelakaan lalulintas di kota Bandung dipengaruhi oleh lebar jalan, jumlah simpang tanpa lampu lalulintas dan volume lalulintas. Semakin banyak jumlah simpang tanpa lampu lalulintas pada suatu ruas jalan, kecelakaan lalulintas akan meningkat. Pada jalan yang lebih lebar dan volume lalulintas lebih tinggi, kecelakaan cenderung berkurang.

2. Model Prediksi Kecelakaan atau persamaan matematis yang dapat memperkirakan jumlah kecelakaan lalulintas sebagai fungsi dari grometrik dan lingkungan jalan, adalah sebagai berikut :

$$
Y=9,756+3,439 X_{4}-1,162 X_{2}
$$

dengan :

$\mathrm{Y}=$ Jumlah kecelakaan lalulintas pada suatu segmen jalan per tahun

$\mathrm{X}_{2}=$ Lebar Jalan $(\mathrm{m})$

$\mathrm{X}_{4}=$ Jumlah simpang tanpa lampu lalulintas suatu ruas/segmen jalan (bh)

Persamaan matematis tersebut diatas memiliki koefisien korelasi (R) sebesar 0,766 dan koefisien determinasi $\left(\mathrm{R}^{2}\right)$ sebesar 0,587. Artinya korelasi linier atau derajat hubungan antara jumlah kecelakaan lalulintas dengan lebar jalan dan jumlah simpang tanpa lampu lalulintas adalah 76,6 \% dan 58,73\%. Variasi dari kecelakaan lalulintas bisa dijelaskan oleh variasi lebar jalan dan jumlah simpang tanpa lampu lalulintas. Berdasarkan koefisien korelasi dan determinasi yang cukup kuat (lebih besar dari $50 \%$ ), persamaan diatas layak dipertimbangkan 
penggunaannya untuk keperluan identifikasi dan penyusunan rangking lokasi rawan kecelakaan

\section{DAFTAR PUSTAKA}

.Bonneson, J.A., and Mc Coy, P.T. (1997). "Effect of Median Treatment on Urban Arterial Safety an Accident Prediction Model". Transportation Research Record 1581, Transportation Research Board, Washington, D.C.

Bowman, B.L., Vecellio, R.L., and Miao, J. (1995). "Vehicle and Pedestrian Accident Models for Median Locations". Journal of Transportation Engineering., ASCE, 121(6).

Drew, D.R. (1968). " Traffic Flow Theory and Control". McGraw-Hill Series in Transportation.McGraw-Hill Book Company. New York, N.Y.

Evans, L. (1991). "Traffic Safety and The Driver". Van Nostrand Reinhold, New York.

Hair, J.F.,et.al. (1988). "Multivariate Data Analysis", Prentice-Hall International, Inc., New Jersey.

Direktorat Jendral Bina Marga (1996). "Indonesian Highway Capacity Manual". Jakarta.

Khisty, C.J. (1990). "Transportation Engineering : An Introduction”. PrenticeHall, Inc. Englewood Cliffs, N.J.

Myers, R.H. (1990). "Classical and Modern Regression with Application". PWS KENT Publishing Company. Boston, M.A..

Ogden, K.W., Taylor, S.Y. (1999). "Traffic Engineering and Management". Institute of Transport Studies, Monash University, Australia.

Oglesbly, C.H. \& Hick, R.G. (1982).“ Highway Engineering”. Jhon Willy \& Soons Inc. New York, N.Y.

Departemen Permukiman dan Prasarana Wilayah. (2004). "Pedoman Penanganan Lokasi Rawan Kecelakaan”. Jakarta.

Sailendra, A.B. (1986). “Pengenalan Faktor Penyebab Kecelakaan Lalulintas Dari Aspek Prasarana Jalan”. Balai Litbang Kimbangwil - Puslitbang Teknologi Prasarana Jalan. Bandung.
Santosa, W. (2003). " Strategi Peningkatan Keselamatan Lalulintas di Jalan Raya". Orasio dies natalis ke-43, Fakultas Teknik Universitas Katolik Parahyangan. Bandung.

Vogt, A. (1999). "Accident Model fpr Rural Intersections : Four-Lane by Two-Lane Stop Controlled and Two Lane by Two Lane Signalized". Federal Highway Administration Report FHWA-RD-99-128. Washington, DC.

Ziad, S., and Tarek, S. (2001). "Evaluating Safety of Urban Arterial Roadways." Journal Transportation Engineering, ASCE, 127(2). 